\title{
Ketoprofen Loaded in Natural Rubber Latex Transdermal Patch for Tendinitis Treatment
}

\author{
Juliana Ferreira Floriano ${ }^{1,7}$ - Natan Roberto de Barros ${ }^{2,3,8}$ • José Luiz Ferreira Cinman ${ }^{4}$ \\ Rosangela Gonçalves da Silva ${ }^{2,3}$ • Augusto Villela Loffredo ${ }^{4}$ - Felipe Azevedo Borges ${ }^{2,3}$. \\ Ana Maria Queiros Norberto ${ }^{5}$ Ana Laura Destro Chagas ${ }^{6}$ Bruna Cambraia Garms ${ }^{2,3}$. \\ Carlos Frederico de Oliveira Graeff ${ }^{1} \cdot$ Rondinelli Donizetti Herculano $^{3}$
}

Published online: 10 October 2017

(C) Springer Science+Business Media, LLC 2017

\begin{abstract}
Ketoprofen is an analgesic with potent antiinflammatory activity against acute inflammation, subacute inflammation, for the acute and long-term treatment of various inflammatory pathologies, as rheumatoid arthritis and colonic adenocarcinoma. In order to minimize the incidence of systemic events related to ketoprofen, the transdermal drug delivery system development has been most important. The advantages of using natural rubber latex membranes include not only the reduction of adverse systemic events, but also the suitability of the low cost of the material together with its physicochemical properties such as flexibility, mechanical stability, surface porosity and water vapor
\end{abstract}

Juliana Ferreira Floriano

juli@ibb.unesp.br

Natan Roberto de Barros natan501@ hotmail.com

José Luiz Ferreira Cinman

jlcinman@gmail.com

Rosangela Gonçalves da Silva

roseziquinelli@hotmail.com

Augusto Villela Loffredo

augusto_villela@hotmail.com

Felipe Azevedo Borges

felipeazevedoborges@hotmail.com

Ana Maria Queiros Norberto

ana.norberto@usp.br

Ana Laura Destro Chagas

ana-laurad@hotmail.com

Bruna Cambraia Garms

bruna_garms@hotmail.com

Carlos Frederico de Oliveira Graeff

graeff@fc.unesp.br

Rondinelli Donizetti Herculano

rond@fcfar.unesp.br permeability, and besides being a biocompatible material also presents biological activity to stimulate the angiogenesis, being able to be used in tissue repair. This study demonstrated that ketoprofen was successfully incorporated into natural latex membranes for drug delivery. FTIR indicated that the drug did not interact chemically with the membrane. Moreover, the natural latex membranes released $60 \%$ of the ketoprofen incorporated in $50 \mathrm{~h}$. SEM images indicated that a portion of the drug was present on the membrane surface, being this portion responsible for the burst release. The tensile tests showed that the addition of the drug into the natural latex membrane did not influence on the polymer

School of Sciences, São Paulo State University (UNESP), 14-01 Eng. Luiz Edmundo Carrijo Coube Avenue, Bauru 17033-360, Brazil

2 Institute of Chemistry, São Paulo State University (UNESP), 55 Prof. Francisco Degni Street, Araraquara 14800-900, Brazil

3 School of Pharmaceutical Sciences, São Paulo State University (UNESP), Km 01, Araraquara-Jaú Road, Araraquara 14801-902, Brazil

4 School of Sciences, Humanities and Languages, São Paulo State University (UNESP), 2100 Dom Antônio Avenue, Assis 19806-900, Brazil

5 Faculty of Medicine, São Paulo University (USP), 3900 Bandeirantes Avenue, Ribeirão Preto 14040-900, Brazil

6 UFTM - ICBN, 330 Manoel Mendes Square, Biochemistry Section, Uberaba, Minas Gerais 38015-050, Brazil

7 Department of physics, School of Sciences, São Paulo State University (UNESP), 14-01 Eng. Luiz Edmundo Carrijo Coube Avenue, Bauru 17033-360, Brazil

8 Pharmaceutical Science Center, Institute of Chemistry, São Paulo State University (UNESP), 55 Prof. Francisco Degni Street, Araraquara 14800-900, Brazil 
mechanical behavior. In addition, drug-natural latex membranes presented no red blood cell damaging effects. Our data shows that the ketoprofen loaded natural latex membranes is a promising system for sustained drug delivery which can be used to minimize the adverse side effects of high dose systemic drug delivery.

Keywords Natural rubber latex · Transdermal drug delivery system $\cdot$ Ketoprofen $\cdot$ Anti-inflammatory . Biomaterial

$\begin{array}{ll}\text { Abbreviations } \\ \text { DNRL } & \text { Deproteinized natural rubber latex } \\ \text { FTIR } & \text { Fourier transform infrared } \\ \text { GS } & \text { Gentamicin sulfate } \\ \text { NCT } & \text { Nicotine } \\ \text { NRL } & \text { Natural rubber latex } \\ \text { NSAIDs } & \text { Anti-inflammatory drugs } \\ \text { PTFE } & \text { Polytetrafluoroethylene } \\ \text { SEM } & \text { Scanning electron microscopy } \\ \text { TDDS } & \text { Transdermal drug delivery systems } \\ \text { PBS } & \text { Phosphate buffered saline }\end{array}$

\section{Introduction}

Currently the development of new drug delivery systems has intensified, including transdermal drug delivery systems (TDDS) due to the fact that a drug rarely can reach a specific target in the body in adequate concentrations to cause the expected therapeutic effect when it is managed in aqueous solution, or in a conventional form, besides physical and chemical instability, among others problems [1,2].

TDDS shows many advantages in drug delivery, as it avoids hepatic first pass metabolism, potentially decrease side effects, improve patient compliance, minimize the incidence of systemic events [3]. TDDS have been designed as an alternative route for systemic drug delivery [4].

TDDS is a good alternative in order to minimize the incidence of systemic events related to anti-inflammatory drugs (NSAIDs) as ketoprofen [5]. The ketoprofen was synthesized by RhBne-Poulenc Research Laboratories, Paris, in 1967, it belongs to a group of substituted 2-phenylpropionic acids, its molecular weight is 254.29 and presents the structural formula (2-(3-benzolpheny1)-propionic acid), see Fig. 1 [6].

The ketoprofen is extensively used as analgesic in chronic pain conditions, displayed potent activity against acute inflammation, subacute inflammation, for the acute and long-term treatment of various inflammatory pathologies, as rheumatoid arthritis and colonic adenocarcinoma [7]. Ketoprofen showed in carrageenin-induced abscesses in rat to be 20 times more potent than ibuprofen, 80 times more potent than phenylbutazone, and 160 times more potent than<smiles>C[C@H](C(=O)O)c1cccc(C(=O)c2ccccc2)c1</smiles>

Fig. 1 Ketoprofen structural formula

aspirin in reducing inflammation. Ketoprofen is one of the most powerful inhibitors of cyclo-oxygenase at concentrations well within the range of therapeutic plasma levels. Moreover, may attenuate cell-mediated inflammation and thus retard the progression of tissue destruction in inflamed joints $[8,9]$.

Despite ketoprofen effectiveness in various treatments, it presents toxic effects in the gastrointestinal (hemorrhage, nausea, dyspepsia, epigastric discomfort, diarrhea, constipation and flatulence) and renal systems as well as in the liver [10]. In order to minimize the incidence of systemic events related to ketoprofen, the TDDS development has been most important. Recently, biopolymers have been used in the fabrication of transdermal membranes due to their excellent biocompatibility [11]. Particularly, Natural Rubber Latex (NRL) is an excellent candidate in order to produce TDDS, besides biocompatibility and bioactivity (high angiogenic potential), it presents flexibility, mechanical stability, surface porosity and permeability, are cheap and abundant materials $[12,13]$.

NRL is a product extracted from rubber trees. The most common source of NRL is Hevea brasiliensis, NRL is a mixing colloidal rubber particles stabilized by a thin layer of phospholipids and proteins (Fig. 2), containing about 40-45\% weight of rubber (poly (cis-1,4-isoprene)), 4-5\% weight of non-rubber constituents such as proteins, lipids, carbohydrates and sugar, and $50 \%$ of water $[14,15]$. Membranes produces with NRL demonstrated success in many applications as an occlusive mechanical barrier favouring osteogenesis, as a source of gradual release of substances with osteogenic potentials, excellent results in skin replacement, promoting healing in burned areas, and angiogenesis [16].

Using the critical size defect model in rabbits, NRL showed to be effective in the bone repair process, and proved superior to PTFE membranes, presenting numerous advantages [18].

The potential of NRL membranes used as TDDS has been demonstrated. Barros et al. [19] revealed the effectiveness of NRL membrane as a model in the release of peptides with pharmacological interest in a study using oxytocin. Similar result were obtained using NRL membranes containing Diclofenac as a model system for transdermal patches [20, 

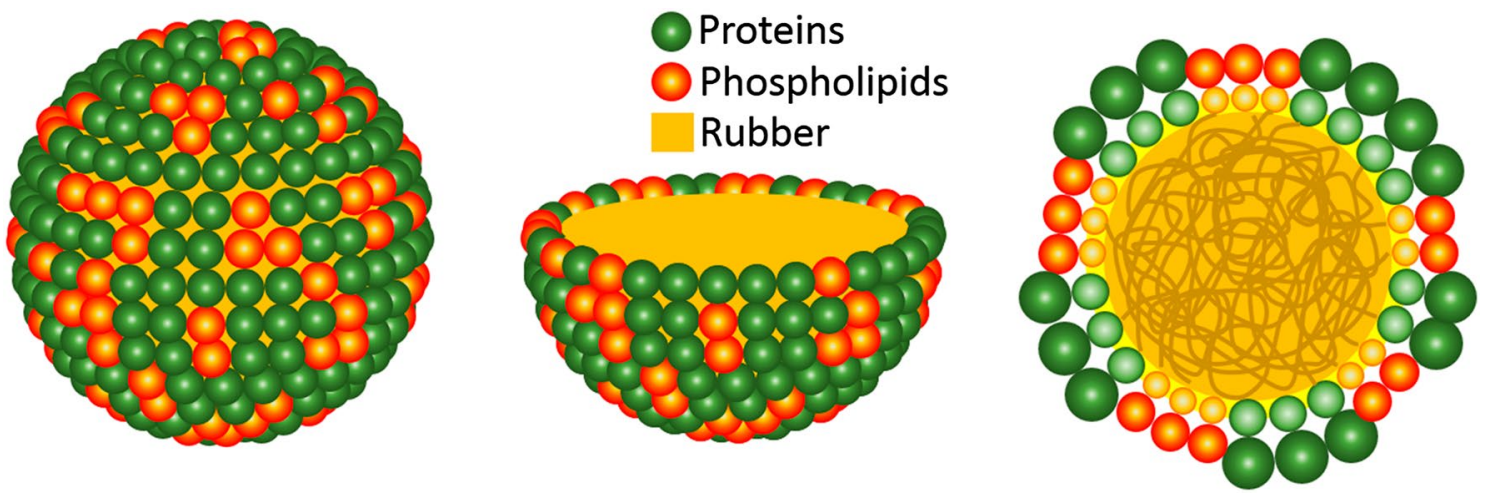

Fig. 2 Suggested schematic representation of an NRL particle [17]

21]. In other study, deproteinized NRL (DNRL) was used to prepare Nicotine (NCT) transdermal patches in combination with PVA and HPMC blends [22, 23]. NRL films loaded with Gentamicin sulfate (GS) was demonstrated to have potential use as medicated wound dressing due to the good antimicrobial activity against Staphylococcus aureus and Pseudomonas. aeruginosa [24].

In this study, we developed a novel TDDS using ketoprofen loaded NRL membranes. Results showed that $23.94 \mathrm{mg}$ $(60 \%)$ of the incorporated drug in NRL membrane was released after $50 \mathrm{~h}$ in solution. Hemolysis assay using the materials (NRL, ketoprofen and NRL-ketoprofen) showed no hemolytic effects (compounds and mixtures). Furthermore, Scanning Electron Microscopy (SEM), Fourier Transform Infrared (FTIR) and mechanical tests showed that the membrane is adequate for biomedical applications.

\section{Experimental Section}

\section{Materials}

The NRL used in this study was commercial high-ammonia from BDF Rubber Latex Co. Ltd. (producer and distributor of concentrated NRL, Guarantã, Brazil) of about $60 \%$ dry rubber content, 4-5\% weight of non-rubber constituents such as proteins, lipids, carbohydrates, and $35 \%$ of water. This NRL was obtained mixing two clones: RRIM 600 and PB 235 (Lot: 01703/13). After extraction, ammonia was used to keep the NRL liquid (pH 10.20). The NRL protein content reduction was performed by centrifugation at $8000 \times g$. The centrifugation method used does not eliminate all proteins present in NRL, only high molecular weight proteins responsible for allergic and cytotoxic reactions obtaining the Natural Rubber Latex Biomedical [25]. The cream fraction after centrifugation was redispersed to make the desired $60 \%$ of dry rubber content latex and then washed twice by centrifugation to reduce the protein content on the solution.
Ketoprofen $\left(\mathrm{C}_{16} \mathrm{H}_{14} \mathrm{O}_{3}\right)$ was obtained in gel capsules, without excipients. Each of them contained $100 \mathrm{mg}$ of drug in powder form. The capsules were purchased from Callithea Pharmaceutics Ltd., Brazil. The drug has been dissolved with ethanol, and adjustment to $90 \%$ aqueous solution to avoid NRL coagulation, at $25{ }^{\circ} \mathrm{C}$ (room temperature).

\section{Membrane Production}

The drug was incorporated by mixing $6 \mathrm{~mL}$ of NRL with $4 \mathrm{~mL}$ of ketoprofen solution $\left(10 \mathrm{mg} \mathrm{mL}^{-1}\right)$. These membranes were prepared by pouring the NRL + ketoprofen solution in a stainless steel plate with $5.00 \pm 0.05 \mathrm{~cm}$ diameter and $1.00 \pm 0.01 \mathrm{~mm}$ thick. Typically, the membranes were left for 2 days to guarantee full polymerization before use.

\section{Ketoprofen Delivery System}

To evaluate the ketoprofen release, NRL membranes were placed in $1600 \mathrm{~mL}$ of phosphate buffered saline (PBS) solution ( $\mathrm{pH}$ 7.4), from which aliquots were collected during an interval ranging from 0 to $250 \mathrm{~h}$. The drug released into the solution was monitored by measuring the UV-Vis spectra with a BEL ENGINEERING SF200 ADV spectrophotometer, as ketoprofen has a maximum absorption at $259 \mathrm{~nm}$. The experiments were carried out in triplicate.

\section{Scanning Electron Microscopy (SEM)}

Membranes surfaces were examined at $\times 300$ and $\times 1500$ magnification using High-Resolution Scanning Electron Microscope (FEG-SEM; JEOL model 7500F) with $2 \mathrm{kV}$, take-off angle of $35^{\circ}$ and gold as conductor material. Three aleatory areas were analyzed to perform the analysis. 


\section{Fourier Transform Infrared (FTIR)}

The FTIR spectra of pure NRL, ketoprofen powder and NRL-ketoprofen were used to identify functional groups (amines, amides, aromatic rings, alcohol, phenols, between others), besides providing the study by possible interactions between NRL and drug. The samples were measured directly by Attenuated Total Reflection (ATR) method using a TENSOR 27 (Bruker, Germany) (4000-400 $\mathrm{cm}^{-1}$ ) source: HeNe laser; detector: DLaTGS with a resolution of $4 \mathrm{~cm}^{-1}$ and 32 scans.

\section{Mechanical Tests}

Tensile tests on the specimens were carried out on a DL2000(EMIC) testing machine, with a 50kgf load cell at a speed of $500 \mathrm{~mm} \mathrm{~min}^{-1}$ (according to ASTM D412) and elongated until failure. The values were converted to stress-strain curves and the Young's modulus was calculated from the initial linear part (0-5\% elongation).

\section{Hemolytic Activity}

The hemolytic activity of the ketoprofen solution, pure NRL membrane, and ketoprofen loaded in NRL was investigated according to Onuma et al. [26]. Sheep blood (5\% defibrinated) from NewProv Bioscience, lot: 16324M, Brazil was centrifuged at $3000 \times g$ for $10 \mathrm{~min}$. The materials were washed four times with PBS (pH 7.4) by centrifugation at $3000 \times g$ for $5 \mathrm{~min}$ and suspended in the same buffer. The samples were extracted according to ISO 10993-12:2006, the extractions were performed in PBS (pH 7.4) at $37^{\circ} \mathrm{C}$ for $24 \mathrm{~h}$ and the extraction ratio was $200 \mathrm{mg} \mathrm{mL}^{-1}$. Serial dilutions of samples were used to determine the percentage of hemolysis (Table 1). The final volume in each well was $200 \mu \mathrm{L}$. Then $200 \mu \mathrm{L}$ of $1 \%(\mathrm{v} / \mathrm{v})$ suspension of erythrocyte (EA) was added to each well. The wells containing complement-free buffer were used as standard with a zero degree of hemolysis (0\%); to attain $100 \%$ hemolysis, and 200 $\mu \mathrm{L}$ of Triton X-100 1\% (v/v) was used instead of the buffer. The plate was incubated at $37{ }^{\circ} \mathrm{C}$ for $1 \mathrm{~h}$ in a Shaker Incubator (Quimis, Brazil) and then the absorbance at $540 \mathrm{~nm}$ was determined in each well in an Epoch Microplate Spectrophotometer (BioTek, USA). Less than 5\% hemolysis was regarded as nontoxic effect level in our experiments.
The percent hemolysis was calculated using the formula $100 \times\left(\mathrm{A}_{\text {sample }}-\mathrm{A}_{\text {blank }}\right) /\left(\mathrm{A}_{\text {Triton }}-\mathrm{A}_{\text {blank }}\right)$.

\section{Results and Discussion}

Figure 3 shows the absorbance intensity as a function of ketoprofen concentration in solution. Each drug concentration was made in triplicate, where the estimated error was minor as 5\%. The calibration curve shows a Lambert-Beers Law behaviour.

Figure 4 shows the ketoprofen release as a function of time. The large bolus of drug released before stability is called "burst release" $(0-24 \mathrm{~h})$ due to the drug close or adsorbed on the surface of the NRL membrane [27, 28].

The slower release process, also called "stable profile" $(24-50 \mathrm{~h})$, is associated with the ketoprofen diffusing slowly through the matrix (inner portion of the polymeric matrix). The ketoprofen release depends mainly on the amount of encapsulated material (as a reservoir). Recent studies have shown that $59.08 \%$ of ciprofloxacin was released by the NRL membranes [29], while $68.40 \%$ of Bovine Serum Albumin (BSA) [1] and $45 \%$ of oxytocin peptide was released by the same polymer [19].

The experimental data were fitted using a bi-exponential function, the characteristic times were found to be 13 and $1 \mathrm{~h}$. The total amount of drug released by the membranes in $1600 \mathrm{~mL}$ aqueous solution was $23.94 \mathrm{mg}$ (60\%).

Aravindaram et al. [30] formulated a biopolymer based transdermal film loaded with ketoprofen. Diffusion studies showed that $91.28 \%$ of ketoprofen was release by the material up to $8 \mathrm{~h}$. Al-Nasi et al. [31] developed ketoprofen microspheres fabricated from biodegradable polymers (polylactic acid and polylactic-co-glycolic acid). The release profile of ketoprofen from the different formulations was $\mathrm{pH}$ dependent (100\% at $\mathrm{pH} 7.4$ and $35 \%$ at $\mathrm{pH} 1.2)$ up to $24 \mathrm{~h}$. Rajesh et al. [4] developed transdermal films loaded with ketoprofen using sodium alginate and xanthan gum. The polymeric blend released $78.8-92.8 \%$ of drug up to $8 \mathrm{~h}$. Tous et al. [32] entrapped the ketoprofen into calcium alginate beads. The results showed that $10-15 \%$ of the drug was released after $4 \mathrm{~h}$ in $\mathrm{pH} 1$, while $80-90 \%$ of ketoprofen was release in $\mathrm{pH} 7.4$ at $8 \mathrm{~h}$. Anh et al. [33] incorporated the ketoprofen into eudragit RS polymeric nanoparticles. The authors observed the released percentage of ketoprofen was $62.5 \%$ after $4 \mathrm{~h}$ in PBS $\mathrm{pH} 7.4$.
Table 1 Serial dilutions of samples for the hemolytic test

\begin{tabular}{lrrrrrrr}
\hline Concentrations & \multicolumn{1}{c}{1} & \multicolumn{1}{c}{ 2 } & \multicolumn{1}{c}{3} & \multicolumn{1}{c}{5} & \multicolumn{1}{c}{6} & 7 \\
\hline NRL $(\%)$ & 100 & 50 & 25 & 12 & 6 & 3 & 1.5 \\
ketoprofen $\left(\mu \mathrm{g} \mathrm{mL}^{-1}\right)$ & 1280 & 640 & 320 & 160 & 80 & 40 & 20 \\
NRL-ketoprofen $(\%)$ & 100 & 50 & 25 & 12 & 6 & 3 & 1.5 \\
\hline
\end{tabular}



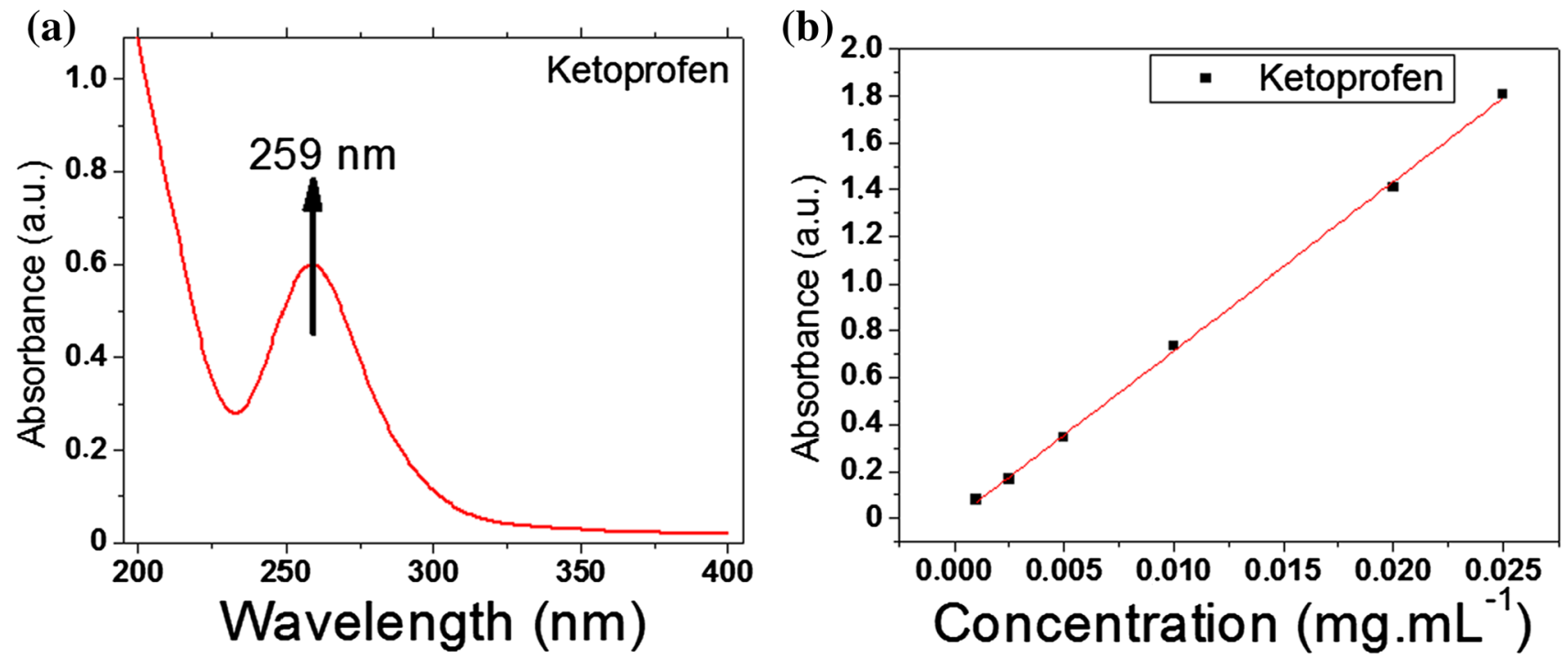

Fig. 3 a Ketoprofen spectrum in solution. b Absorbance intensity as a function of ketoprofen concentration in solution

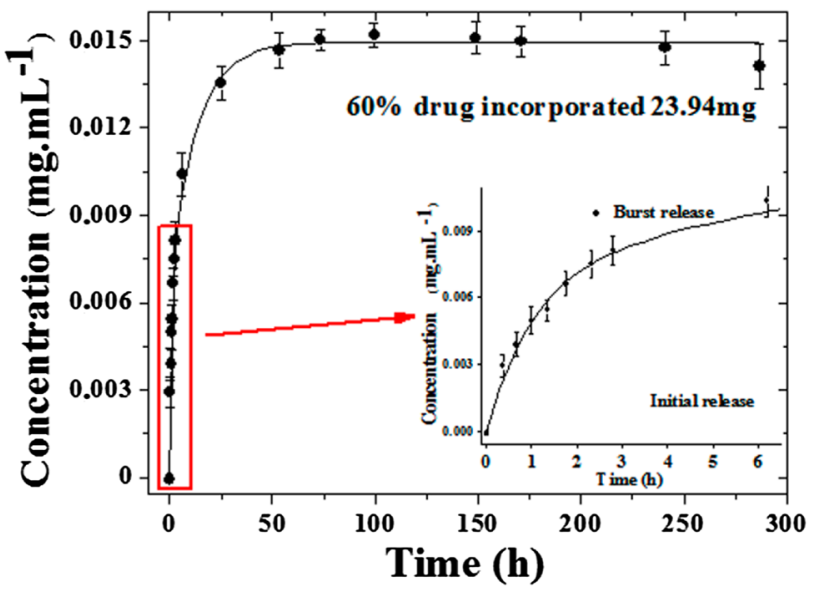

Fig. 4 Ketoprofen release kinetics by the NRL membranes. Notice that the inset shows the initial release $(0-6 \mathrm{~h})$
SEM analysis was performed to evaluate changes in the surface of NRL membranes with drug addition. Figure 5 shows the SEM images obtained from pure NRL membrane, ketoprofen powder, and NRL-ketoprofen membrane. Note that a reasonable amount of drug is found on the membranes surfaces forming solid aggregates (Fig. 5c). This ketoprofen moiety on the surface is responsible for the fast release during the first hours, according to Barros et al. [25], Borges et al. [34] and Aielo et al. [21].

Figure 6 (blue line) shows that the NRL membrane is composed of the polymer poly $\left(\right.$ cis-1,4-isoprene) $\left(837 \mathrm{~cm}^{-1}\right)$. This absorption is the most important to identify NRL and it is character of $\mathrm{R}_{2} \mathrm{C}=\mathrm{CHR}($ cis-1,4) function in according with Herculano et al. [35] and Floriano et al. [12]. The band around $3040 \mathrm{~cm}^{-1}$ is assigned to $=\mathrm{CH}$ stretching of between 2963 and $2845 \mathrm{~cm}^{-1}$, to $\mathrm{CH}_{3}$ and $\mathrm{CH}_{2}$ stretching
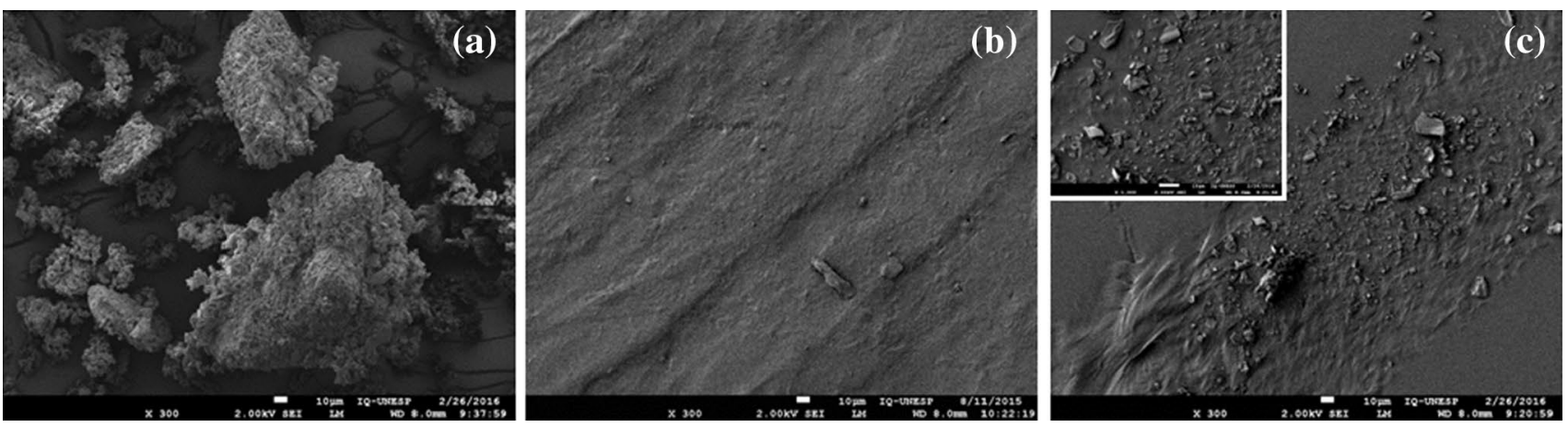

Fig. 5 SEM visualization of: a ketoprofen $\times 300$; $\mathbf{b}$ NRL membrane $\times 300$; $\mathbf{c}$ ketoprofen loaded NRL membrane $\times 300$. The inset shows the surface with higher magnification $(\times 1500)$ 


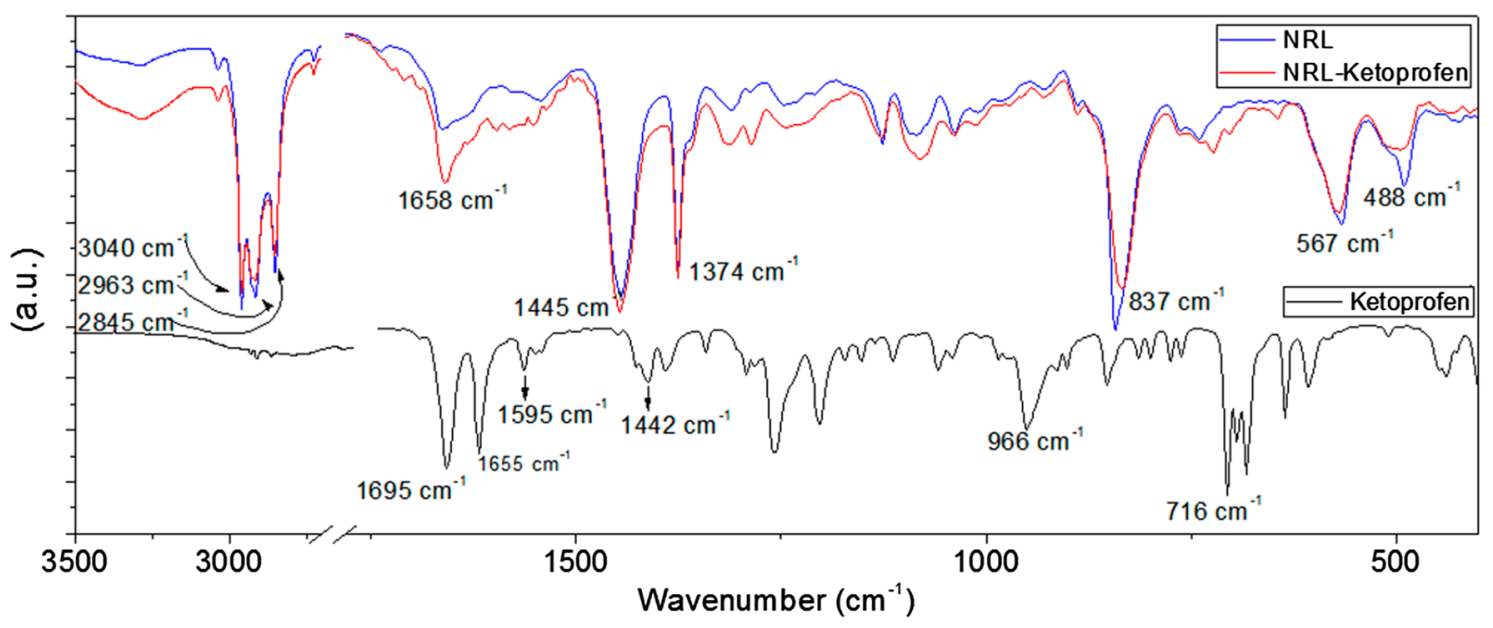

Fig. 6 FTIR spectra of pure NRL, ketoprofen powder and NRL-ketoprofen membranes. (Color figure online)

of $1658 \mathrm{~cm}^{-1}$, to $\mathrm{C}=\mathrm{C}$ stretching of 1445 and $1374 \mathrm{~cm}^{-1}$, to $\mathrm{CH}_{2}$ and $\mathrm{CH}_{3}$ deformation, respectively; $837 \mathrm{~cm}^{-1}$ to $=\mathrm{CH}$ out-of-plane bending, 567 and $488 \mathrm{~cm}^{-1}$ to $\mathrm{C}-\mathrm{C}-\mathrm{C}$ deformation.

Ketoprofen FTIR spectrum (Fig. 6-black line) showed the characteristic absorptions at 1695 and $1655 \mathrm{~cm}^{-1}$ corresponding to acid carbonyl $(\mathrm{C}=\mathrm{O})$ group and ketonic carbonyl $(\mathrm{C}=\mathrm{O})$ group, at $1595 \mathrm{~cm}^{-1}$ due to presence of aromatic $\mathrm{C}=\mathrm{C}$ stretch, at $1442 \mathrm{~cm}^{-1}$ due to presence of $\mathrm{CH}-\mathrm{CH}_{3}$ deformation. Finally, the peaks at 716 and $966 \mathrm{~cm}^{-1}$ are due to presence of $\mathrm{C}-\mathrm{H}$ out of plane deformation.

Additionally, the ketoprofen loaded NRL membrane FTIR spectrum (Fig. 6-red line) showed that there are no significant changes in the NRL absorption peaks position after ketoprofen incorporation. The ketoprofen peaks intensities, when incorporated into the membrane decreased because the drug molecules are embedded in polymeric matrix. The characteristic bands observed to NRL were preserved, proving no significant interaction between the drug and the membrane with good compatibility.

The tensile test was performed to evaluate the influence of ketoprofen addition on the NRL membranes mechanical behavior. Figure 7 shows that both NRLs present elastomeric behavior, with high elongation and a low Young's modulus.

The new material became stiffer and brittle, with a smaller plastic deformation (less ductile). Table 2 resumes the results of the tensile mechanical test.

The addition of drug reduced 1.25 times the elongation at break, while the tensile strength value is maintained. The incorporation of ketoprofen leads to the increase of hydrogen bonding, acting as reinforcement or creating cross-linking which resulted in loss of elasticity. In addition, the Young's

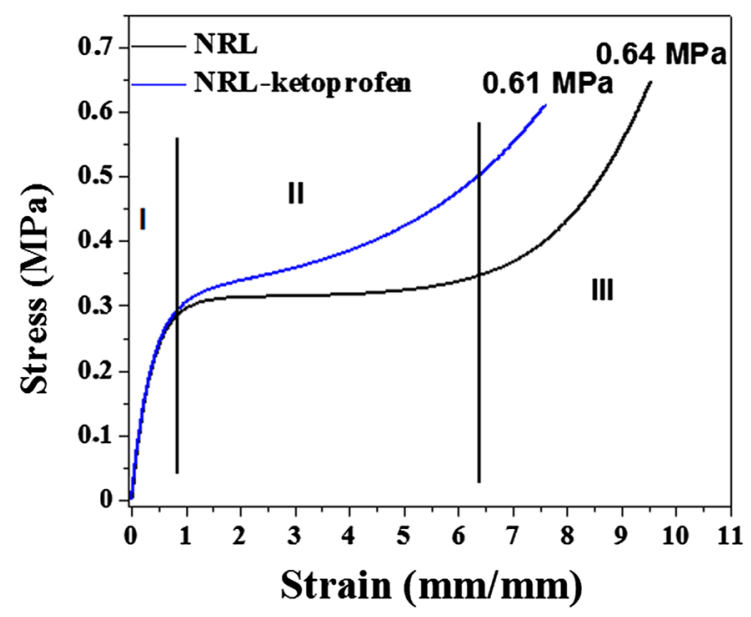

(a)

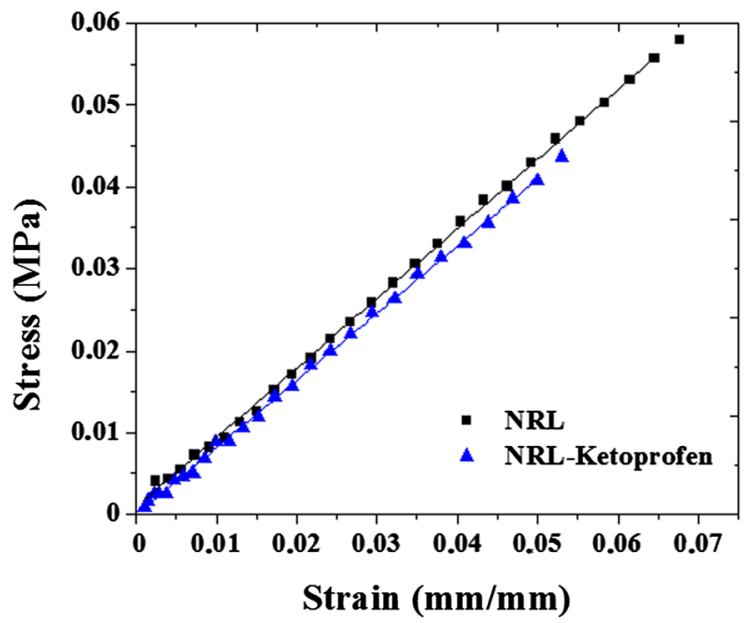

(b)

Fig. 7 Representative stress-strain curves NRL membrane and ketoprofen loaded membrane (a); Initial linear part of the stress-strain curves (b) 
Table 2 Mechanical properties of NRL membranes

\begin{tabular}{llcc}
\hline & Young modulus $(\mathrm{MPa})$ & Tensile strength $(\mathrm{MPa})$ & Elongation (\%) \\
\hline NRL & $0.8503 \pm 0.0054$ & $0.6466 \pm 0.050$ & $952.29 \pm 0.70$ \\
NRL-ketoprofen & $0.8195 \pm 0.0054$ & $0.61065 \pm 0.037$ & $758.52 \pm 16.00$ \\
\hline
\end{tabular}

modulus of the membranes were similar. These results are in agreement with Murbach et al. [30], that found that the addition of the ciprofloxacin to NRL, turned it stiffer and brittle, with smaller plastic deformation. In addition, our results are similar to Floriano et al. [18], who evaluated the mechanical behavior of NRL membranes. In this study, the Young's modulus and tensile strength of Hevea brasiliensis (IAN 873) were 0.63 and $0.68 \mathrm{MPa}$, respectively. Moreover, we observed that all samples presented good reproducibility, indicating homogeneity.

The interactions between NRL, ketoprofen and NRLketoprofen was also studied by hemolysis experiments. The hemolysis assay was performed to evaluate the cytolytic activity of the materials used. The release of hemoglobin was used to quantify the membrane-damaging properties. Our results show that NRL and NRL-ketoprofen extracts have no hemolytic effects (Fig. 8) indicating no detectable disturbance of the red blood cell membranes, with hemolysis levels less than 5\%. These results are similar to previous works in the literature, Borges et al. [36] used calcium phosphate $(\mathrm{Ca} / \mathrm{P})$, Barros et al. [19] used oxytocin peptide, and Barros et al. [25] used desmopressin peptide in NRL membranes. The test was realized according to the international standard ISO 10993-4:2006, showing that the membrane NRL-ketoprofen has no cytolytic activity.

No other group of researchers have so far conducted studies on the ketoprofen sustained release using natural rubber latex membranes as a solid support. Therefore, all the results obtained contribute to the science of biomaterials and drug delivery systems.

Some studies using a biopolymer based transdermal film loaded with Ketoprofen, demonstrated in in vitro and in vivo studies, that the developed film have great potential for transdermal drug delivery to achieve adequate therapeutic plasma concentration [30]. This effect can explaned because the patch facilitates ketoprofen delivery for a long period of time, thus the drug remains continually present in the tissue subjacent to the site of application [36]. Besides the total systemic bioavailability of ketoprofen administered via a patch is no more than $10 \%$ of that reported for ketoprofen administered orally. Making possible tissue concentrations high enough to exert a therapeutic effect and plasma concentrations remain low enough to not result in systemic adverse events caused by elevated serum NSAID levels. Due to this factors the treatment by ketoprofen patch demonstrated efficacy in the treatment of nonarticular rheumatisms [37]. (a)

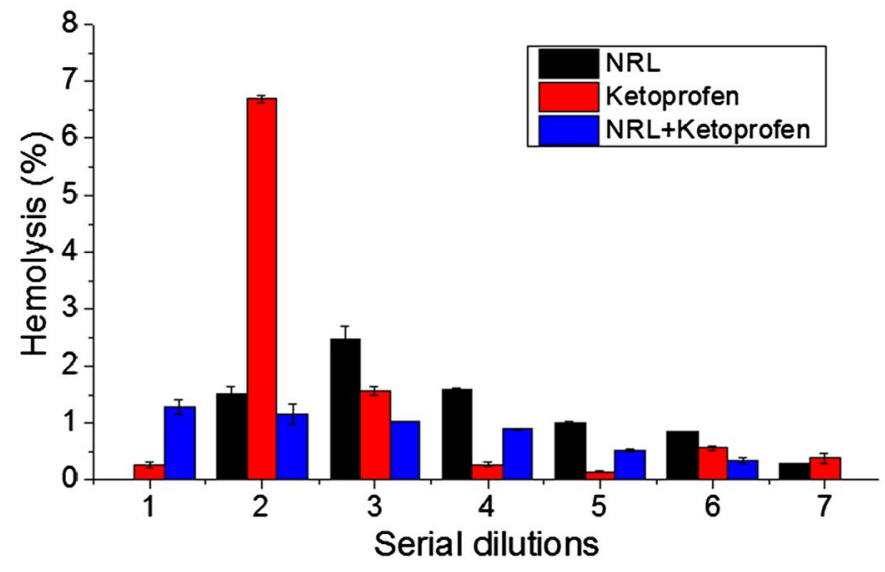

(b)
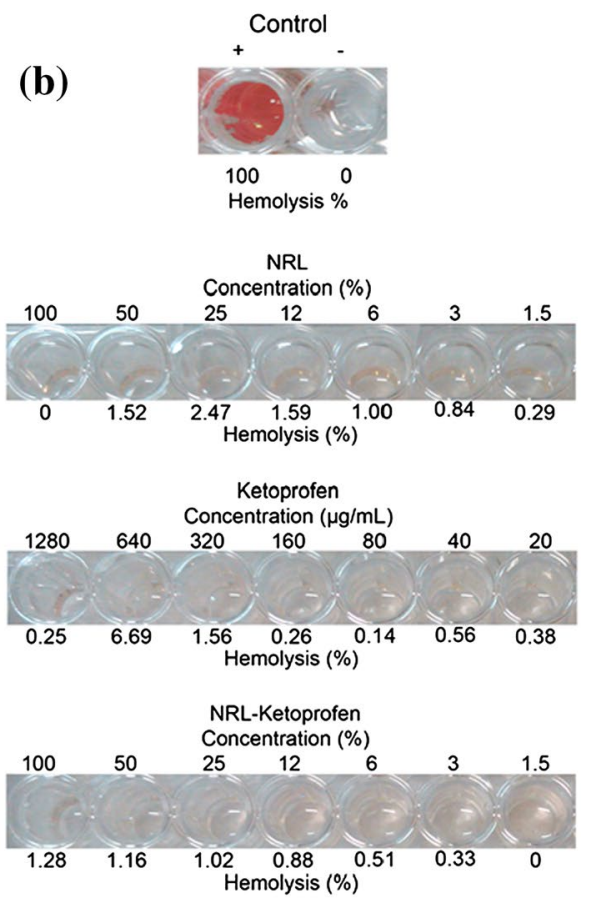

Fig. 8 Hemolysis assay activity as a function of materials concentrations 
The advantages of using NRL as a TDDS for ketoprofen include not only the reduction of adverse systemic events, but also the suitability of the low cost of the material together with its physicochemical properties, besides being a biocompatible material also presents biological activity to stimulate the angiogenesis, being able to be used in tissue repair.

\section{Conclusion}

This study demonstrated that ketoprofen was successfully incorporated into NRL membrane as model for TDDS. FTIR indicated that the drug did not interact chemically with the membrane. Moreover, the NRL membranes released $60 \%$ of the ketoprofen incorporated up to $50 \mathrm{~h}$. SEM images indicated that a portion of drug was present on the surface of the polymeric matrix, where this portion is responsible for the burst release. The tensile tests showed that the addition of drug into NRL membrane had no influence on the mechanical behavior (tensile strength and Young modulus) of polymer. In addition, the ketoprofen, NRL membrane and drug-NRL membrane presented no cell damaging effects, where the hemolysys level was $<5 \%$. In conclusion, the findings support the hypothesis that the ketoprofen loaded NRL membrane is a promising approach for sustained drug delivery which can be used to minimize the adverse side effects of high dose.

Acknowledgements Our thanks to Prof. Dr. Joaquin Coutinho Netto (in memoriam), for his great contribution to the study and understanding of the bioactive properties of latex.

Funding This work was supported by CAPES, CNPq (Process: 470261/2012-9) and FAPESP (Processes 2014/17526-8, 2011/17411-8).

Availability of Data and Materials All data analysed during the current study that are not already included in this published article, are available from the corresponding author on reasonable request.

Authors' Contributions This work was carried out in collaboration between all authors. JFF, NRB, JLFC, JLPG, RGS, AVL, FAB, AMQN and ALDC realized the experimental techniques. JFF, AVL and FAB realized the kinetic release of extract, NRB and ALDC realized the SEM, mechanical resistance and FTIR analyses. JLFC, JLPG and AMQN realized the hemolysis assay. The mechanism of release was evaluated by NRB and RGS. NRB, AVL, FAB, BCG and ALCD had corrected the typographical and grammatical errors. Finally, the format of the paper has been updated by RDH and CFOG. RDH and CFOG are advisors and the head of laboratory. All authors read and approved the final paper.

\section{Compliance with Ethical Standards}

Conflict of interest The authors declare that they have no competing interests.

\section{References}

1. Herculano RD, Silva CP, Ereno C, Guimaraes SAC, Kinoshita AMO, Graeff CFO (2009) Natural rubber latex used as drug delivery system in guided bone regeneration (GBR). Mater Res 12:253-256

2. Hussain A, Khan GM, Shah SU, Shah KU, Rahim N, Wahab A, Rehman AU (2012) Development of a novel ketoprofen transdermal patch: effect of almond oil as penetration enhancers on in-vitro and ex-vivo penetration of ketoprofen through rabbit skin. Pak J Pharm Sci 25:227-232

3. Rajesh K, Pitchaimani R (2006) Formulation of transdermal drug delivery system. Curr Drug Discov Technol 3:279-285

4. Rajesh N, Siddaramaiah, Gowda DV, Somashekar CN (2010) Formulation and evaluation of biopolymer based transdermal drug delivery. Int J Pharm Pharm Sci 2:142-147

5. Ramesh G, Vamshi VY, Kishan V, Madhusan RY (2007) Development of nitrendipine transdermal patches: in vitro and ex vivo characterization. Curr Drug Deliv 4:69-76

6. Thomas G, Kantor MD, Ketoprofen: (1986) A review of its pharmacologic and clinical properties. Pharmacotherapy. doi:10.1002/j.1875-9114.1986.tb03459.x

7. Maestrelli F, Zerrouk N, Cirri M, Mura P (2015) Comparative evaluation of polymeric and waxy microspheres for combined colon delivery of ascorbic acid and ketoprofen. Int J Pharm. doi:10.1016/j.ijpharm.2015.02.073

8. Julou L, Guyonnet JC, Ducrot R, Fournel J, Pasquet J (1976) Ketoprofen (19.583 R.P.) (2-(3-benzoylphenyl)-propionic acid). Main pharmacological properties-outline of toxicological and pharmacokinetic data. Scand J Rheumatol Suppl 1976:33-44

9. Dawson W, Boot JR, Harvey J, Walker JR (1982) The pharmacology of benoxaprofen with particular reference to effects on lipoxygenase products formation. Eur J Rheumatol lnflamm 5:61-68

10. Rahbek I (1976) Gastroscopic evaluation of the effect of a new anti-rheumatic compound, ketoprofen (19.583 R.P.), on the human gastric mucosa. A double-blind cross-over trial against acetylsalicylic acid. Scand J Rheumatol 1976:63-72

11. Barry BW (2001) Novel mechanisms and devices to enable successful transdermal drug delivery. Eur J Pharm Sci. doi:10.1016/ S0928-0987(01)00167-1

12. Floriano JF, Mota LSLS, Furtado EL, Rossetto VJV, Graeff CFO (2014) Biocompatibility studies of natural rubber latex from different tree clones and collection methods. J Mater Sci 25:461-470

13. Neves-Junior WFP, Graeff CFO, Ferreira M, Mulato M, Bernardes MS, Coutinho-Netto J (2006) Elastic properties of natural rubber tubes produced by dip-coating. J Appl Polym Sci 100:702-707

14. Narayanan E, Yee HC (1973) Clonal nursey studies in Hevea. II. Relationship between yield and girth. J Rubber Res Inst Malays 23:332-338

15. Othman AB, Hepbur C, Hasma H (1993) Influence of non-rubber constituents on elastic properties of natural rubber vulcanizates. Plast Rubber Compos Process Appl 19:185-194

16. Silva GA, Coutinho OP, Ducheyne P, Reis RL (2007) Materials in particulate form for tissue engineering applications in bone. $\mathrm{J}$ Tissue Eng Regen Méd 1:97-109

17. Nascimento RM, Faita FL, Agostini DLS, Job AE, Guimarães FEG, Bechtold IH (2014) Production and characterization of natural rubber-Ca/P blends for biomedical purposes. Mater Sci Eng. doi:10.1016/j.msec.2014.02.019

18. Floriano JF, Neto FC, Mota LSLS, Furtado EL, Ferreira RS, Barraviera B, Gonçalves PJ, Almeida LM, Borges FA, Herculano RD, Graeff CFO (2016) Comparative study of bone tissue accelerated regeneration by latex membranes from Hevea brasiliensis and Hancornia speciosa. Biomed Phys Eng Express. doi:10.1088/2057-1976/2/4/045007 
19. Barros NR, Miranda MCR, Borges FA, Mendonça RJ, Cilli EM, Herculano RD (2016) Oxytocin sustained release using natural rubber latex membranes. Int J Pep Res Ther. doi:10.1007/ s10989-016-9523-y

20. Barros NR, Chagas PAM, Borges FA, Gemeinder JLP, Miranda MCR, Garms BC, Herculano RD (2015) Diclofenac potassium transdermal patches using natural rubber latex biomembranes as carrier. J Mater. doi:10.1155/2015/807948

21. Aielo PB, Borges FA, Romeira KM, Miranda MCR, Arruda LB, Filho PNL, Drago BC, Herculano RD (2014) Evaluation of sodium diclofenac release using natural rubber latex as carrier. Mat Res 17:146-152

22. Pichayakorn W, Suksaeree J, Boonme P, Amnuaikit T, Taweepreda W, Ritthidej GM (2012) Nicotine transdermal patches using polymeric natural rubber as the matrix controlling system: effect of polymer and plasticizer blends. J Membr Sci. doi:10.1016/j. memsci.2012.04.017

23. Suksaeree J, Boonme P, Taweepreda W, Ritthidej GC, Pichayakorn W (2012) Characterization, in vitro release and permeation studies of nicotine transdermal patches prepared from deproteinized natural rubber latex blends. ChemEng Res Des. doi:10.1016/j. cherd.2011.11.002

24. Phaechamud T, Issarayungyuen P, Pichayakorn W (2016) Gentamicin sulfate-loaded porous natural rubber films for wound dressing. Int J Biol Macromol. doi:10.1016/j. ijbiomac.2016.01.040

25. Barros NR, Miranda MCR, Borges FA, Gemeinder JLP, Mendonça RJ, Cilli EM, Herculano RD (2017) Natural rubber latex: development and in vitro characterization of a future transdermal patch for enuresis treatment. Int J Polym Mater Po. doi:10.1080/ 00914037.2017.1280795

26. Onuma Y, Satake M, Ukena T, Roux J, Chanteau S, Rasolofonirina N, Ratsimaloto M, Naoki H, Yasumoto T (1999) Identification of putative palytoxin as the cause of clupeotoxism. Toxicon. doi:10.1016/S0041-0101(98)00133-0

27. Borges FA, Bolognesi LFC, Treco A, Drago BC, Arruda LB, Lisboa-Filho PN, Perri EG, Graeff CFO, Santos AG, Miranda MCR, Herculano RD (2014) Natural rubber latex: study of a novel carrier for Casearia sylvestris Swartz delivery. ISRN Polym Sci. doi:10.1155/2014/241297
28. Garms BC, Borges FA, Santos RE, Nigoghossian K, Miranda MCR, Miranda IU, Daltro P, Scarpari SL, Giagio RJ, Barros NR, Alarcon KM, Drago BC, Gemeinder JLP, Oliveira BH, Nascimento VMG, Loffredo AL, Herculano RD (2017) Characterization and microbiological application of ciprofloxacin loaded in natural rubber latex membranes. Br J Pharm Res. doi:10.9734/ BJPR/2017/31614

29. Murbach HD, Ogawa GJ, Borges FA, Miranda MCR, Lopes R, Barros NR, Mazalli AVG, Silvia RG, Cinman JLF, Drago BC, Herculano RD (2014) Ciprofloxacin release using natural rubber latex membranes as carrier. Int J Biomater. doi:10.1155/2014/157952

30. Aravindaram AS, Nandan RVS, Gowda DV, Khan MS (2011) Development and evaluation of Ketoprofen loaded biopolymer based transdermal film. Scholars Res Library 3:233-244

31. Al-Nasi AA, Al-Tahami KA (2016) Preparation, characterization, and in vitro release of ketoprofen loaded polymeric microspheres. Int J PharmTech Res 9:313-321

32. Tous S, Fathy M, Fetih G, Gad SF (2014) Preparation and evaluation of ketoprofen-loaded calcium alginate beads. Int J Pharm Tech Res 6:1100-1112

33. Anh NT, Chi NT, Tran TK, Dao TPT, Le NTN, Chien DM, Hoai NT (2012) Preparation and characterization of ketoprofen loaded eudragit RS polymeric nanoparticles for controlled release. Adv Nat Sci Nanosci Nanotechnol. doi:10.1088/2043-6262/3/4/045015

34. Borges FA, Almeida-Filho E, Miranda MCR, dos Santos ML, Herculano RD, Guastaldi AC (2015) Natural rubber latex coated with calcium phosphate for biomedical application. J Biomater Sci Polym Ed. doi:10.1080/09205063.2015.1086945

35. Herculano RD, de Queiroz AAA, Kinoshita A, Oliveira ON Jr, Graeff CFO, Herculano RD (2011) On the release of metronidazole from natural rubber latex membranes. Mat Sci Eng C. doi:10.1016/j.msec.2010.09.007

36. Mazières B (2005) Topical ketoprofen patch. Drugs R D 6:337-444

37. Mazières B, Rouanet S, Guillon Y, Scarsi C, Reiner V (2005) Topical ketoprofen patch in the treatment of tendinitis: a randomized, double blind, placebo controlled study. J Rheumatol $32: 1563-1570$ 